\title{
The role of personality traits in development of overtraining syndrome in elite athletes in adolescence: a review study
}

\author{
Role osobnostních rysů v rozvoji syndromu přetrénování \\ u vrcholových sportovců v období adolescence: přehledová studie
}

\author{
Sára Hutečková, Kateřina Bartošová, Zuzana Frydrychová
}

Masaryk University, Brno, Czech Republic

\begin{abstract}
Sport performance of elite athletes is accompanied by long-term intensive training. Without adequate period of rest this intensive training can cause overreaching of young athlete. Stress, fatigue, lack of rest and load before and during competitions increase the risk of overtraining that leads to a decrease of performance, persistent fatigue, reduced ability to compete and mood disorders. The main purpose of this study is to map the theoretical background and previous empirical research work to integrate existing knowledge about a role of personality traits in development of overtraining syndrome of young elite athletes and to create basis for a further research in the field of sport psychology. The review of quantitative researches covered the period from 1999 to 2016. Nine relevant studies fulfilling the criteria were chosen. Neuroticism and Conscientiousness were found to be significant predictors of athlete's performance. The differences between athletes and physically inactive population were found for dimension of Neuroticism, Extraversion and Conscientiousness. Differences between individual and team sports were found in all five dimensions of personality. Some differences occur also in female and male athletes and athletes competing on national and international level of competition compared to those competing on regional level of competition. Due to the symptoms of overtraining syndrome and areas that can be affected by it, it is possible to assume certain changes in personality traits, caused by long-term overload of the athletes. High level of Neuroticism and Conscientiousness are considered as possible risk factors for development of overtraining syndrome.
\end{abstract}

\begin{abstract}
Abstrakt
Sportovní výkony vrcholových sportovců doprovází dlouhodobý intenzivní trénink, který bez dostatečného obdobi pro relaxaci a zotavení způsobuje prepětí dospívajícího sportovce. Stres, únava, nedostatek odpočinku a vypětí před a při soutěžích zvyšuji riziko přetrénování, které vede k poklesu výkonnosti, pretrvávající únavě, snižení schopnosti konkurenčního boje a poruchám nálad. Hlavním cílem této studie je zmapovat teoretické podklady a doposud provedené výzkumy, integrovat dosavadní znalosti o roli osobnostních rysů v rozvoji syndromu přetrénování u mladých vrcholových sportovců a vytvořit podklady pro další výzkum na poli sportovní psychologie. Přehled kvantitativních studií zahrnuje období od roku 1999 do roku 2016. Bylo vybráno devět relevantních studii, které splňovaly stanovená kritéria. Neuroticismus a Svědomitost se ukázaly být signifikantními prediktory sportovního výkonu. Pro dimenzi Neuroticismus, Extraverze a Svědomitost byly nalezeny rozdily mezi sportovci a nesportovci. Ve všech pěti dimenzích byly nalezeny rozdilly mezi individuálními a týmovými sporty. Některé rozdíly se ve sportu objevují i mezi muži a ženami a mezi sportovci soutěžíími na národní a mezinárodní úrovni soutěže a těmi soutěžícími na regionální úrovni soutěže. Díky symptomům syndromu pretrénování a oblastí, které postihuje, je možné predpokládat určité změny v osobnostních charakteristikách, zpüsobené dlouhodobým přetižením sportovce. Vysoká míra Neuroticismu a Svědomitosti je považována za možný rizikový faktor pro rozvoj syndromu pretrénování.
\end{abstract}


Keywords: adolescence; elite sport; overtraining; personality traits; overload; five-factor model of personality

Klíčová slova: adolescence; vrcholový sport; preteténování; osobnostní charakteristiky; přetížení; pětifaktorový model osobnosti

\section{INTRODUCTION}

Sport plays an important role in physical and mental development, socialization and development of personality traits in children and adolescents. The benefits of regular physical activity such as development of motor and physical skills, strategic thinking, cooperation, respect for the rules or competitiveness can affect an individual's life in many different areas, not only in sport environment (Paulík, 2006). There can be many reasons for sport activity in children and adolescents. On one side sport brings entertainment and fills out the leisure time. It also creates an opportunity and environment for socialization. On the other side many athletes experience pressure from their parents, coaches, peers or media (McCarthy, Jones, \& Clark-Carter, 2008; Smith, 2003; Stroebel, 2006). Increasing frequency and volume of the training sessions is often accompanied by intense pressure, that is focused on success and high performance of elite athletes. Stress, fatigue, lack of rest, injuries associated with the sport activity and exertion before and during competitions can cause overload in young elite athletes (Budgett, 2000; MacKinnon, 2000). Long-term intensive training without sufficient time to fully recover and repeated overload of young elite athlete can contribute to overtraining syndrome (MacKinnon, 2000). Overtraining is manifested by specific symptoms that include physiological and hormonal changes, weakened immune system, and it also affects psychological and social domains, such as changes in emotions, affectivity, social relations etc. (Budgett, 2000; MacKinnon, 2000). Some differences in personality traits can be found in athletes compared to physically inactive population but also among some specific groups of athletes (e. g. individual vs. team sports) (Nia, \& Besharat, 2010). The occurrence of overtraining syndrome also varies in different groups of athletes (Matos, Winsley \& Williams, 2011) and certain personality traits may have an influence on susceptibility to the overtraining syndrome (Hollander, Meyers, \& LeUnes, 1995). The main purpose of this review study is to map the theoretical background and previous empirical research work to integrate existing knowledge about a role of personality traits in development of overtraining syndrome of young elite athletes and to create basis for a further research in the field of sport psychology.

\section{PERSONALITY IN SPORT}

Personality in sport can be understood as an individual unity of personality characteristics, that are relatively stable and manifested in typical way in specific situations (Blahutková \& Pacholík). Despite similar conditions of sport environment, the same intensity and frequency of training load, different athletes react in different ways. There is an increasing need to know athletes' personality characteristics to be able to adapt the training sessions to the current needs and possibilities of the individuals in the sport environment (Jones, 2003; Paulík, 2006; Woodman, \& Hardy, 2003). The personality of young elite athlete can be influenced by many factors such as family environment, school, coaches, peers, socioeconomic status or audience (Blahutková \& Pacholík). The main influence can be seen in family motivational climate connected to parental pressure that modifies a level of anxiety over the season (O’Rourke, Smith, Smoll, \& Cumming, 2011). Also motivational climate created by coach has a great impact on experienced anxiety and self-esteem of an athlete 
(Schwebel, 2015). Young elite athletes need to be able to manage the regular training sessions and competitions and they have to finish the compulsory school attendance. This makes it very difficult to fulfil all obligations and therefore their days are highly structured (Harwood \& Knight, 2009). To conclude it, together all of this requires a great endurance of a young individual.

The relationship between personality traits and sport can have two directions. The first one suggests that certain personality traits may be a predisposition to achieve a better performance. The second one understands achieving higher performance, experiencing success and life changes connected to sport career as a contributing factor to modification of personality traits (Allen \& Laborde, 2014; Egloff \& Gruhn, 1996; Nia \& Besharat, 2010; O’Sullivan, Zuckerman \& Kraft, 1998).

In numerous studies examining the personality in a sport environment (Allen, Greenlees, \& Jones, 2011; Nia \& Besharat, 2010; Piedmont, Hill, \& Blanco, 1999) an athlete's personality is described in terms of five-factor model of personality (McCrae \& Costa, 1996). Piedmont et al. (1999) have already proven that the five-factor model of personality is useful for examining personality in the sport environment. Also Allen et al. (2011) chose the five-factor model of personality to explore the personality traits and their impact on used coping strategies. The five-factor model of personality understands the personality as a system that consists of several components that are defined by five personality traits and interactions between them (McCrae \& Costa Jr, 1999). The first dimension Neuroticism (N) describes the tendency to experience distress, anxiety, depression and impulsive behaviour. Extraversion (E) represents tendency to experience joy, pleasure and other positive emotions. Openness to experience $(\mathrm{O})$ means rich fantasy, many ideas, sensitivity to beauty and own values. Dimension of Agreeableness (A) describes the relationships to other people, altruism, compliance and tendency to trust the others. The last dimension Conscientiousness (C) represents the level of organization, sense of order and self-discipline of the individual (Costa, \& McCrae, 1992; Costa Jr \& McCrae, 1995).

Based on identified five dimensions of personality - Neuroticism, Extraversion, Openness to experience, Agreeableness and Conscientiousness - several personality inventories were created. NEO-PI (Costa \& McCrae, 1985; Costa, \& McCrae, 1992) consists of 181 items that have two forms - self-report (S) and observer ratings (R). The dimension of Neuroticism, Extraversion and Openness include six facet scales each. The dimension of Agreeableness and Conscientiousness do not include any facet scales. NEO-PI-R (Costa, \& McCrae, 1992; Costa Jr \& McCrae, 1995) is the revised version of the personality inventory, that consists of 240 items measuring five dimensions that include 6 facet scales each. The dimensions are identified by 48 items divided by individual facet scales. NEO-FFI (Costa, \& McCrae, 1992) called NEO five factor inventory, consists of 60 items. Each dimension is measured by 12 items and there are no facet scales in this inventory.

In the sport context an athlete's personality plays an important role in his/her performance. Piedmont et al. (1999) examined personality traits as a predictor of athlete's performance. They identified the dimensions of neuroticism and conscientiousness to be significantly connected to performance of athlete in women soccer players. Personality traits also influence interpersonal relationships of athletes and psychological states related to competitions (Allen, \& Laborde, 2014).

\section{FROM TRAINING TO OVERTRAINING}

Sport training is an essential part of sport preparation of an individual that improves endurance, attention, tactic and strategic thinking and develops athlete's personality toward the sport performance. In elite athletes, the training is mentally and physically demanding activity, that focuses on developing physical, social and psychological disposition associated to sport discipline (Lehnert, Novosad, \& Neuls, 2001). 
Young elite athletes are exposed to excessive load, fatigue and high levels of stress during the training sessions and competitions (Faude, Kellmann, Ammann, Schnittker, \& Meyer, 2011). The time needed for regeneration depends on frequency, intensity and difficulty of the training process. The more intensive the training is, the more time to rest an athlete's body requires. If the regeneration is not sufficient, the risk of overtraining increases (Budgett, 2000).

To achieve a required performance, athletes need to train hard and cope with many factors that can have negative effect on actual performance. Especially in elite sport where athletes compete on national and international levels these factors such as stress, fatigue and excessive load can have a great impact on their scores in the competition and inability to cope with them can bring changes in athlete's career (Faude et al., 2011; Lavallee, Sagar, \& Spray, 2009). Stress is considered to be a main factor influencing achieved performance of an athlete. Many athletes perceive their sport success as a source of their self-esteem. Maladaptive stress is connected mainly to fear of failure and negative social evaluation (potentially self-evaluation) (Lavallee et al., 2009). According to Lavallee et al. (2009) the fear of failure affects four domains of athlete's life (well-being, interpersonal behaviour, sport performances and academic results). At first it influences well-being, mainly mood states and emotions (higher level of depression, anxiety, sadness). The effect on interpersonal behaviour is manifested mostly in dysfunctional social interactions and inability to communicate. Athletes feel easily irritated, less sociable and less tolerant. Athletes achieve poorer performances and neglect their school duties that is associated to worsening of school results.

Sport training and performance can be influenced by high level of fatigue resulting from overloading of an athlete's organism and regular physical strain. Fatigue is a normal response to training load. If an athlete respects the time needed for rest and has a possibility to fully recover, the fatigue is compensated. Usually the fatigue disappears during two weeks. In case it persists after two weeks, it is considered to be an abnormal reaction to the load (Budgett, 2000; Lehnert et al., 2001). The fatigue can be accompanied by several manifestations, such as somatic symptoms (digestive system disorders, sleep disturbances, excessive sweating, inability to concentrate, prolonged reaction time) or neuropsychological symptoms (increased irritability, apathy, indecision, changes of character). Overall fatigue leads to uncertainty and decline interest in sport activity (Kučera, Kolář, \& Dylevský, 2011).

Related to fatigue it is necessary to mention excessive load, that is highly connected to training of young elite athletes. Mainly during the period of competitions physical and also mental load increases and athletes must be able to cope with it. Any increase of the load requires adequate time for relaxation (Lehnert et al., 2001). Insensitive increasing of training load and lack of time for recovery can lead to overloading of the body and can manifests by fatigue, decrease of performance and aversion to sport activities. Two weeks should be sufficient to fully recover from excessive load (Nederhof, Lemmink, Zwerver, \& Mulder, 2007).

Many factors (stress, fatigue, excessive load, etc.) influences the risk of development of overtraining. Not always, however, must they lead directly to overtraining. Based on severity of the symptoms, Nederhof, Lemmink, Visscher, Meeusen and Mulder (2006) state three types of overload: functional overreaching (FO), non-functional overreaching (NFO) and overtraining syndrome (OTS).

Functional overreaching is the least serious case of overload and is commonly used by coaches to improve an athlete's performance through adaptation on the level of load (Budgett, 2000; Nederhof et al., 2006) It occurs after an extremely intensive physically demanding training and needs to be balanced by less intense training sessions. If the training load is inappropriately scheduled and the athlete is not ready to adapt to it, the overload can appear. It is accompanied by fatigue and decreased performance. Functional overreaching should disappear within few days. If the 
athlete is regularly overloaded, the non-functional overreaching can occur (Faigenbaum, 2009; Nederhof et al., 2006).

Non-functional overreaching can be caused by extreme fatigue and regular excessive training load without adequate rest (Nederhof et al., 2006). Compared to functional overreaching it does not disappear during several days, but it can persist for several weeks or even months. It is a long-term problem that manifests by fatigue and reduced sport performance, and it affects athlete's career.

Overtraining syndrome is the most serious form of overload. It occurs after long-term intensive training and extreme load and is influenced by training and non-training stressors, monotonous training and inadequate periodization (MacKinnon, 2000). Athletes suffering from this syndrome experience long-term unexplained decrease in their performance, high level of fatigue and many other symptoms such as depression, mood disorders, sleep disorders, loss of appetite, anxiety, feeling of heavy legs, pain in muscles, loss of competitive drive, changes in personality, changes in self-esteem and self-evaluation, problems in social interactions and decrease of motivation etc. (Budgett, 2000; MacKinnon, 2000; Kučera et al., 2011). Overtraining syndrome may last around several months or even years (Nederhof et al., 2006). Kučera et al., (2011) stated that overtraining can appear in two ways. The first one is very sudden and the symptoms are developing very quickly. It is accompanied by several acute problems that cumulate and then can transform into the syndrome. Athletes also often suffer from some somatic diseases. The identification of the syndrome is very difficult. The second way is slower and symptoms occur gradually. Early identification is then easier and coach or parents may start to intervene in time. The treatment of overtraining syndrome is not clearly determined. It is a long-term process. Athletes need a lot of rest, support and slow return to the sport activities (Kučera et al., 2011; Meeusen et al., 2013).

Matos et al., (2011) were examining the incidence of non-functional overreaching and overtraining in elite athletes and found out that higher incidence of non-functional overreaching and overtraining appeared in individual sports rather than in team sports. Also athletes competing on national and international level scored higher in non-functional overreaching and overtraining than those competing on regional level. The last result proved higher incidence of non-functional overreaching and overtraining in women rather than in men.

\section{ATHLETE'S PERSONALITY AND OVERTRAINING SYNDROME}

Overtraining syndrome manifests by many symptoms. Some of them are connected to changes in personality, self-esteem, self-evaluation, emotional lability, irritability or inability to establish and maintain interpersonal relationships (Budgett, 2000; MacKinnon, 2000; Kučera et al., 2011). This review study aims to map the role of personality traits in development of overtraining syndrome of young elite athletes. To achieve this goal, it is necessary to integrate existing knowledge and results from conducted studies.

According to previous researches some relationships between personality and sport participation were found. For example, Egloff and Gruhn (1995) proved that endurance athletes were more extraverted than non-exercisers, but scored comparably in neuroticism and openness. O'Sullivan, Zuckerman and Kraft (1998) found out that team sport athletes scored significantly higher on Activity and lower on Neuroticism. These studies were followed by many others with the intention of mapping the relationships between athlete's personality and sport activities. Review of the relevant literature is provided below. 


\section{METHOD}

The review of quantitative researches covered the period from 1999 to 2016 . This 15 -years period was considered to be a period which covers the most relevant studies concerning personality in the context of sport environment. Relevant researches were searched through electronic database. At first ScienceDirect, ResearchGate, ShapeAmerica, Ingenta Connect, PLOS ONE, SPORT SCIENCE databases were searched through. The total number of found studies was 1228 . The key words used to search the studies were: adolescence, elite sport, overtraining, personality traits, overload, five-factor model of personality. Relevant studies were chosen according to fulfilling the topics personality and sport. In the third phase of the search, studies using the five-factor model of personality were selected. In the last phase, the relevant studies were properly read and studies that did not fulfil the following criteria were eliminated:

i) Quantitative research design of the studies

ii) The aim of the study was to examine the relationship between personality traits and sport participation or performance

iii) The studies used five-factor model of personality defined by Costa and McCrae (1992) and to determine the personality used one of the NEO Personality Inventories

The criteria were selected according to research design and the main aim of the review study, that is mapping the theoretical background and previous empirical research work to integrate existing knowledge about a role of personality traits in development of overtraining syndrome of young elite athletes and to create basis for a further research in the field of sport psychology. In the previous studies the five-factor model of personality has been proven as a suitable model for examining personality traits in the sport context.

\section{RESULTS}

From all searched studies, 9 studies fulfilling the requirements were chosen. The overview of the studies is shown in the following table. 


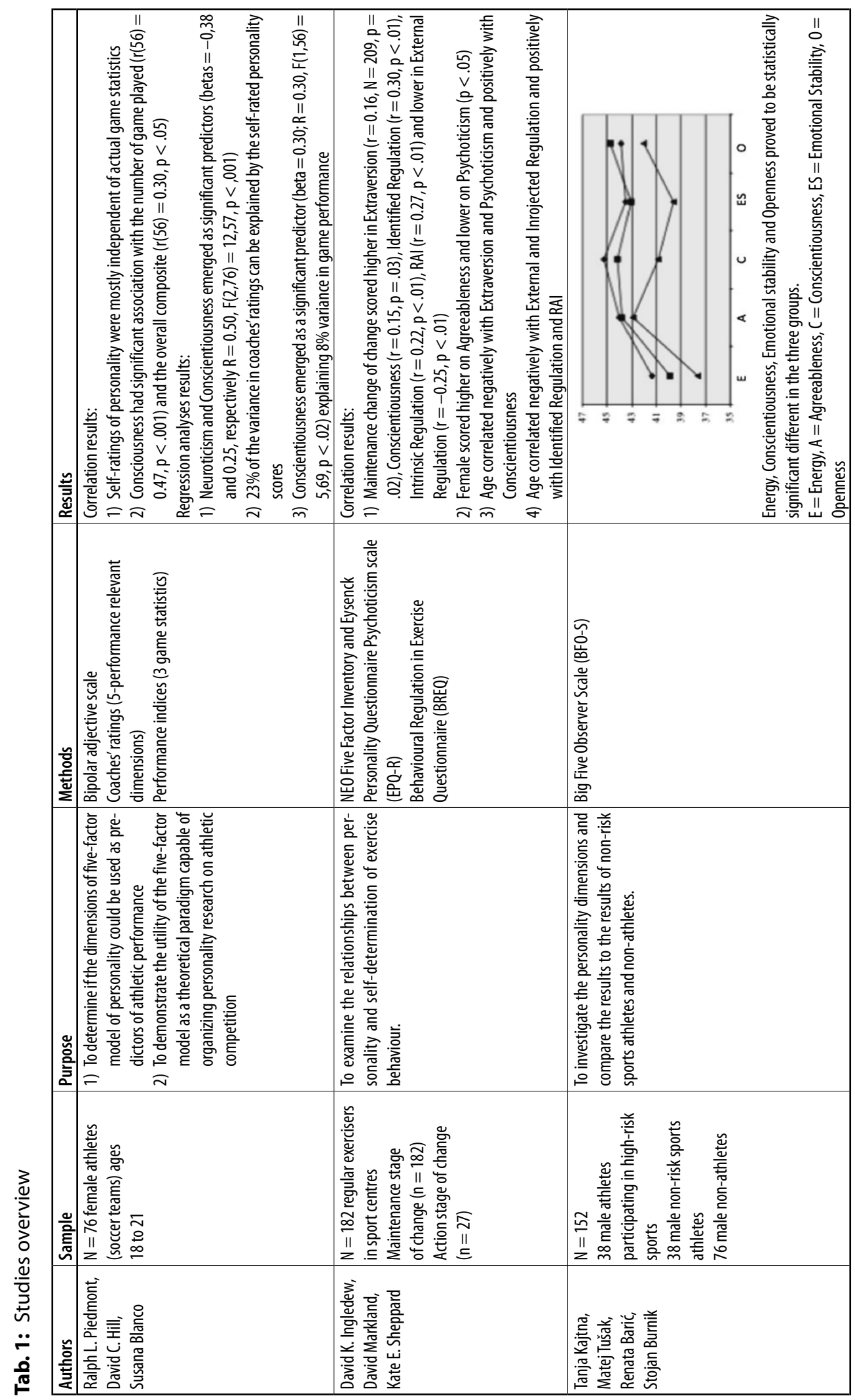




\begin{tabular}{|c|c|c|c|}
\hline & 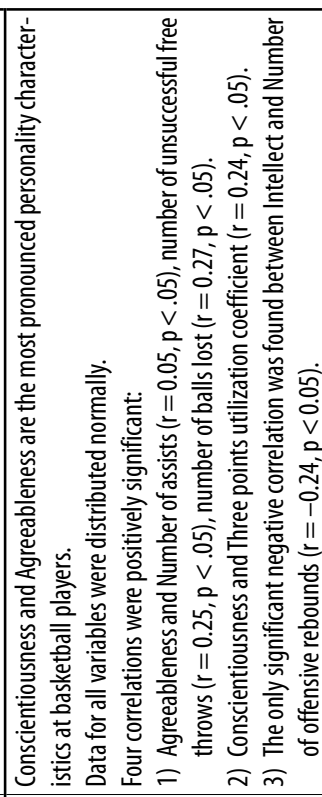 & 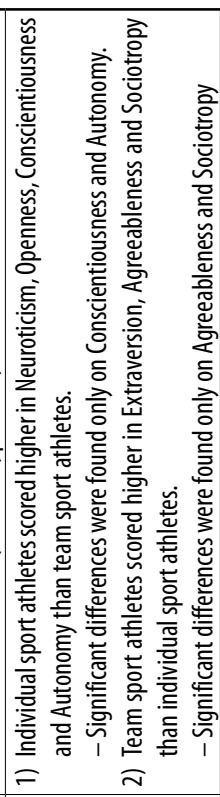 & 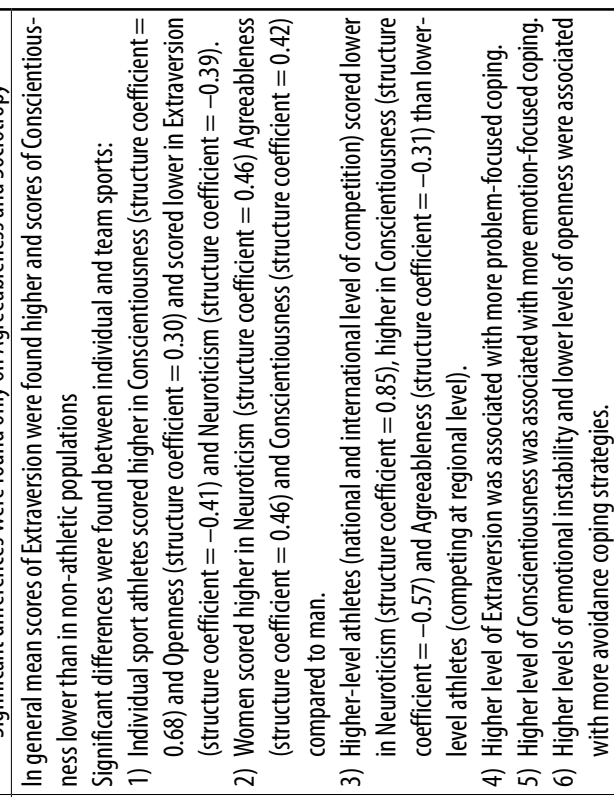 \\
\hline $\begin{array}{l}n \\
0 \\
0 \\
\frac{0}{2} \\
\Sigma\end{array}$ & 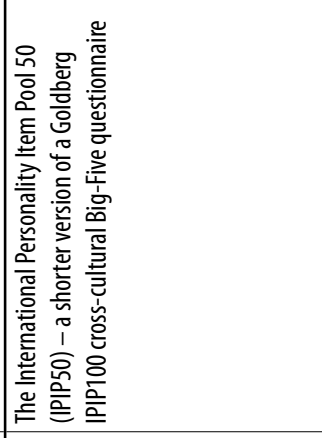 & 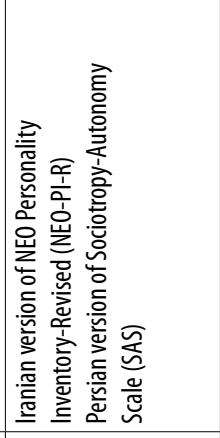 & 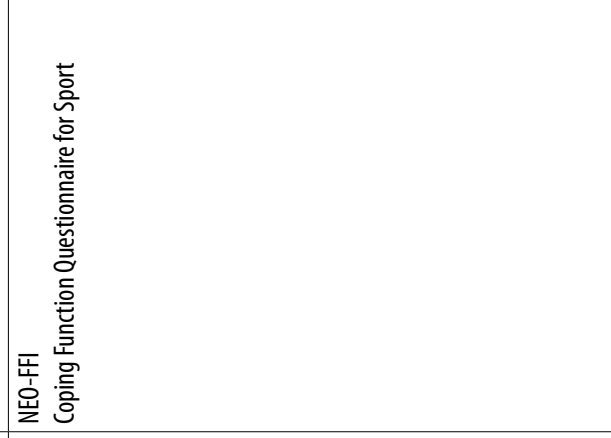 \\
\hline & 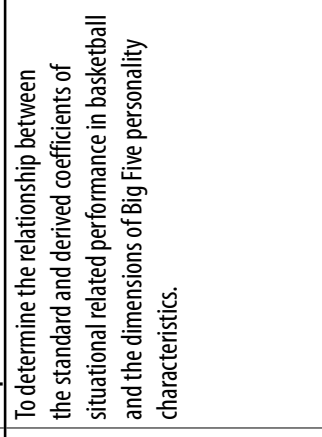 & 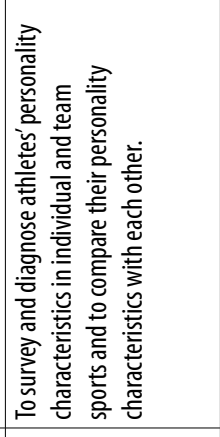 & 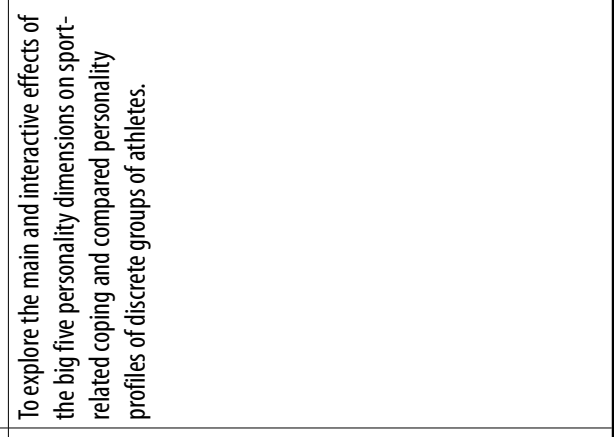 \\
\hline & 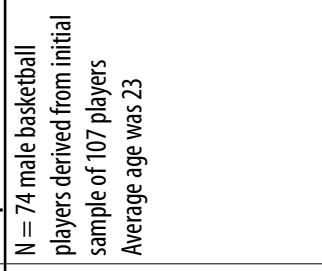 & 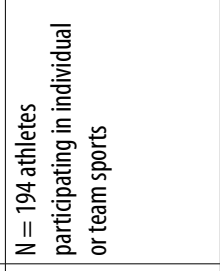 & 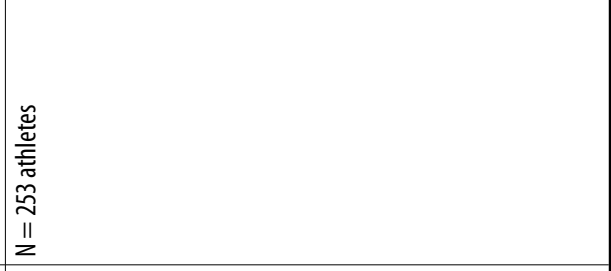 \\
\hline & \begin{tabular}{|} 
言 \\
言 \\
产 \\
商
\end{tabular} & 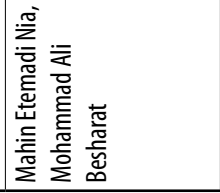 & 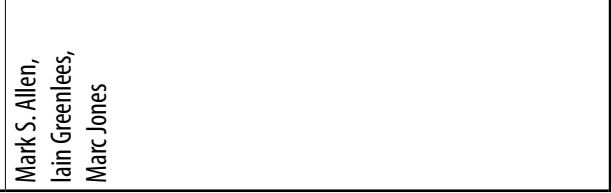 \\
\hline
\end{tabular}




\begin{tabular}{|c|c|c|c|}
\hline & 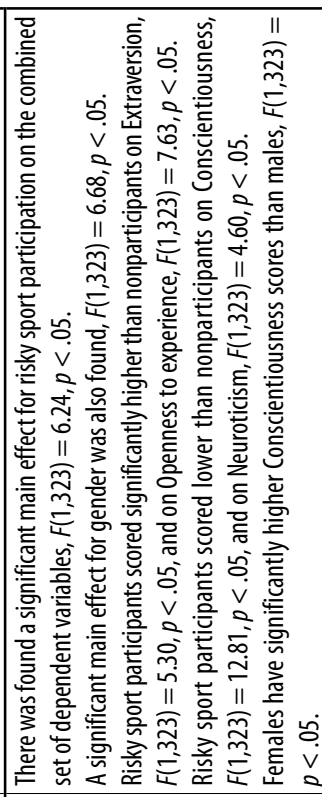 & 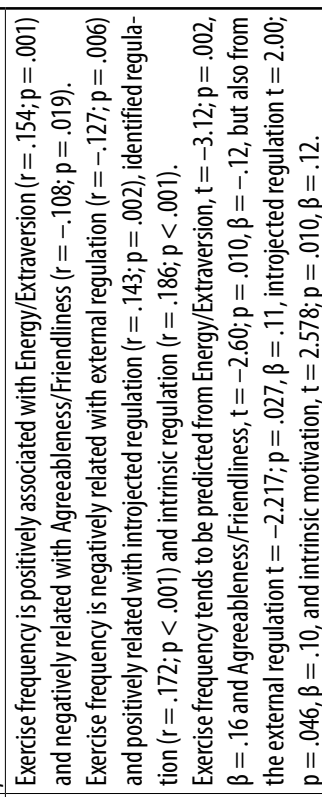 & 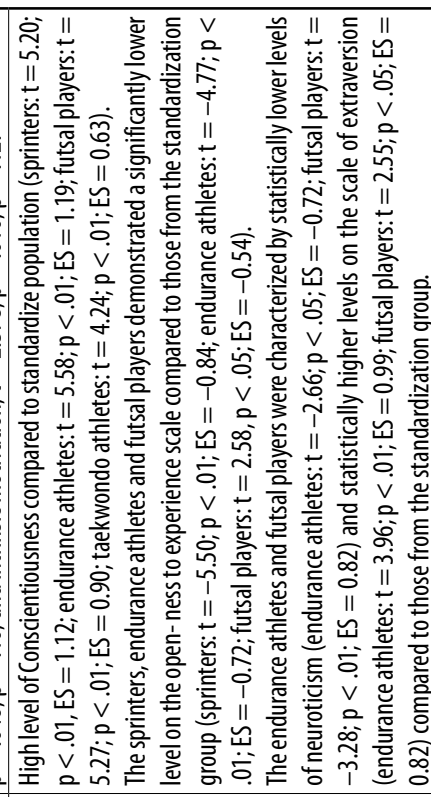 \\
\hline & 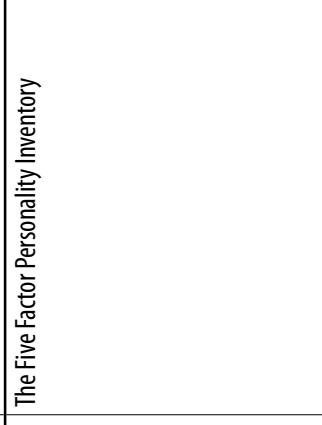 & 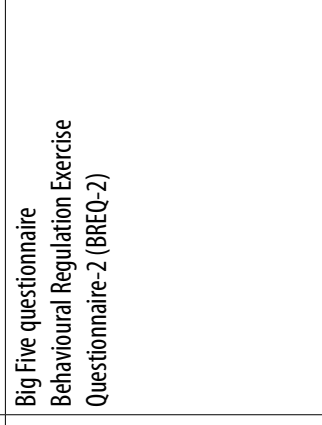 & 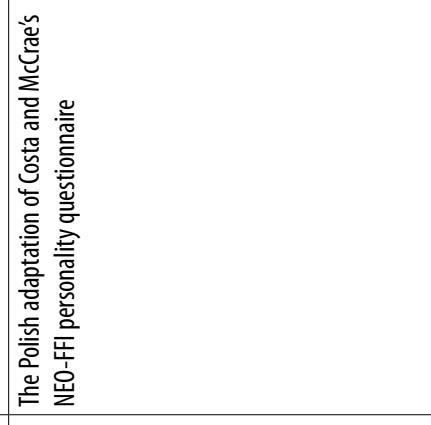 \\
\hline & 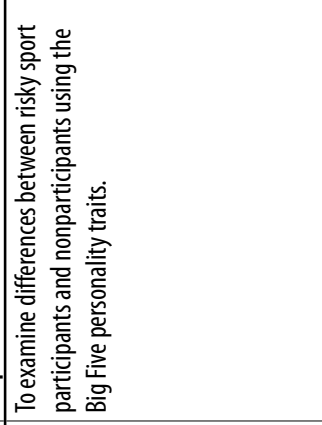 & 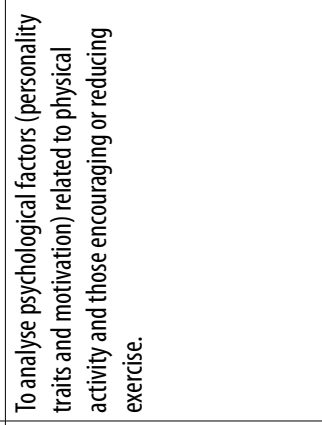 & 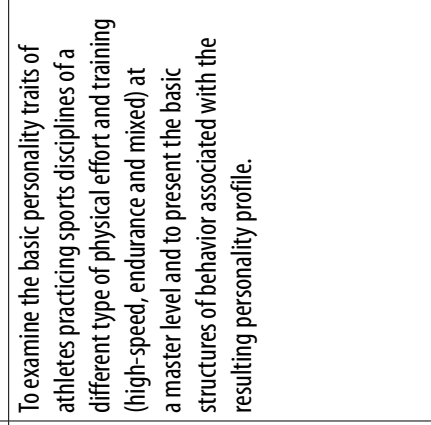 \\
\hline & 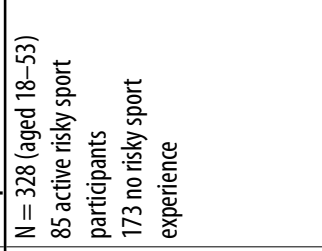 & 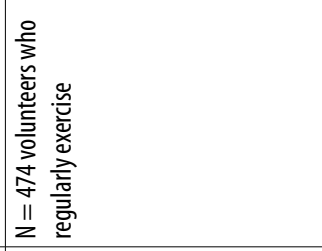 & 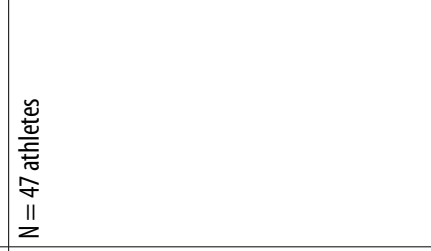 \\
\hline & 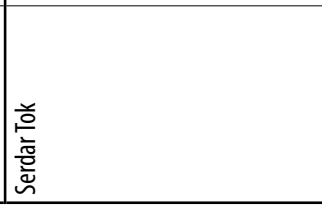 & 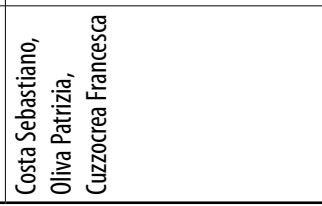 & 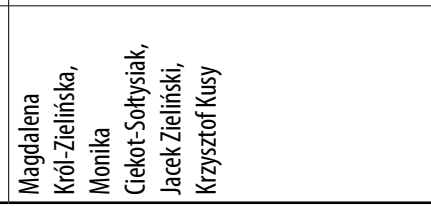 \\
\hline
\end{tabular}




\section{DISCUSSION}

This study has reviewed the existing studies and researches between 1999 and 2016 examining the association between athlete's personality and sport participation with the main intention to integrate the knowledge about this topic and prepare theoretical basis for a research examining the role of personality traits in the development of overtraining syndrome. Although we found many studies exploring personality in the context of sport environment, only 9 of them were deemed relevant, as they fulfilled the selected criteria. Generally, these studies attempted to identify the personality traits in athletes and their association with the participation in sport activities compared to physically inactive population (Costa, Oliva, \& Cuzzocrea, 2014; Ingledew, Markland, \& Sheppard, 2004; Kajtna, Tušak, Barić, \& Burnik, 2004; Tok, 2011) or performance (Piedmont et al., 1999; Sindik, 2010), the differences between personality traits in athletes participating in individual and team sports (Nia, \& Besharat, 2010) or between different groups of athletes (Allen et al., 2011; Król-Zielińska, \& Ciekot-Sołtysiak, 2015). The studies used methods based on fivefactor model of personality (McCrae \& Costa, 1996) examining the five dimensions of personality (Neuroticism, Extraversion, Openness to experience, Agreeableness and Conscientiousness) that was proved to be useful when describing a personality in the context of sport environment (Piedmont et al., 1999). The presented researches match in some results, in other results they diverge. A brief overview of the results in individual dimensions will be presented and discussed.

Neuroticism: The dimension of Neuroticism was found to be a significant predictor of athletic performance in women soccer players (Piedmont et al., 1999). It is connected to the ability to cope with stress, control behaviour and emotions (Costa, \& McCrae, 1992). Athletes in general score lower in Neuroticism than non-exercisers (Nia, \& Besharat, 2010). Sport environment provides many positive emotions such as joy and happiness connected to achieved performance or sport activity itself (Paulík, 2006), it also requires a high level of self-regulation and control of the emotions and behaviour (Slepička, Hošek, \& Hátlová, 2009). Comparing individual and team sports, individual sport athletes score higher in Neuroticism than team sport athletes (Nia, $\&$ Besharat, 2010). These differences were not significant. The explanation for the higher mean score in individual sport athletes could be seen in the awareness that the result depends only on the individual and non-existent team spirit and support. These findings were not consistent with results from another study comparing individual sports and team sports, that examined lower level of Neuroticism in individual sport athletes compared to team sport athletes (Allen et al., 2011). This study states higher level of Neuroticism in women than in men and lower level of Neuroticism in athletes competing on national and international levels than on regional level. The high-level athletes experience more stress connected to the national and international competitions, but also need to be more able to cope with it (Faude et al., 2011). Also athletes participating in risky sports scored lower on Neuroticism than the others (Tok, 2011). The authors explain this finding by the statement that persons that score lower in Neuroticism are emotionally stable and need very intensive stimulus to feel the arousal. That can be the reason they participate in risky sports.

Elite sport environment is associated with high level of stress that can increase the feelings of anxiety and fear (Hanton, Fletcher, \& Coughlan, 2005). The difficulty of the competitions and the pressure of parents and coaches can support this negative feeling that athletes experience (Lavallee et al., 2009). Emotionally unstable individual could have a problem to cope with fear and anxiety, feel hopeless and lose self-confidence and be more vulnerable to develop overtraining. Repeated failure in competitions, decrease of performance, anxiety and depression, mood changes and hostility are the most obvious symptoms of overtraining (Budgett, 2000; MacKinnon, 2000). Long-term overload could cause some changes in personality traits, such as higher level of anxiety, depression, hostility and impulsive behaviour, that are subscales of dimension of Neuroticism (Costa, \& McCrae, 1992). 
Extraversion: Generally, athletes score higher on Extraversion than non-exercisers (Allen et al., 2011). It is connected to the fact, that Extraversion is positively associated to exercise participation and frequency (Costa et al., 2014). As expected, compared to individual sport athletes, team sport athletes seem to be more extraverted (Allen et al., 2011; Nia, \& Besharat, 2010). The explanation can be seen in cooperation in team, where athletes experience team spirit and support from their teammates. Also communication between athletes is an important part of the team activities. Risky sport athletes score also significantly higher on Extraversion than the others (Tok, 2011).

Overtraining affects athlete's level of energy, activity and interpersonal relationships, because it can increase his/her irritability and decrease his ability to communicate and sociability (Budgett, 2000; Lavallee et al., 2009; MacKinnon, 2000). Long-term effect could occur in warmth, gregariousness, activity and positive emotions that are subscales of dimension of Extraversion (Costa, \& McCrae, 1992).

Openness to experience: Not many studies found out some significant results about Openness to experience. The only differences were found in individual and team sports and in risk sports compared to other sports. Individual sport athletes scored higher on Openness to experience than team sport athletes (Allen et al., 2011; Nia, \& Besharat, 2010). In team sports athletes must respect their teammates and also can be influenced by them compared to individual sport athletes. Risky sport athletes also scored higher on Openness to experience than the others (Tok, 2011). The authors explain this finding mainly with the need to try something new and experience an adventure.

Openness to experience includes subscales such as fantasy, feeling, actions, ideas and values (Costa, \& McCrae, 1992). Long-term overload and overtraining can affect mainly experience, values and ideas (Budgett, 2000; MacKinnon, 2000).

Agreeableness: According to Costa et al. (2014) the dimension of Agreeableness is negatively associated with the frequency of exercise. As expected, team sport athletes score significantly higher on Agreeableness than individual sport athletes (Nia, \& Besharat, 2010). Also Agreeableness was found to be the most pronounced personality trait at basketball players (Sindik, 2010). It can be connected to the assumption, that team sport athletes need to cooperate, trust his/her teammates and communicate more than individual sport athletes. Also the authors present the idea that athletes who are more agreeable, choose a team sport rather than individual sport (Nia, $\&$ Besharat, 2010). According to some other findings female athletes score higher on Agreeableness that male athletes (Allen et al., 2011; Ingledew et al., 2004). Also athletes compete at international and national levels of competition score higher on Agreeableness than athletes competing on regional levels (Allen et al., 2011).

Non-functional overreaching and overtraining are accompanied by expressive mood disorders, depression, decreased tolerance and inability to communicate and cooperate with the others. Athletes suffering from overtraining can experience high level of hostility and inability to trust the others. Also altruistic tendencies are typically decreased (Lavallee et al., 2009; MacKinnon, 2000). As the trust, altruism and compliance are a part of the dimension of Agreeableness, the long-term overload could affect this dimension and manifest in low level of Agreeableness (Costa Jr, McCrae, \& Kay, 1995).

Conscientiousness: Generally, Conscientiousness was proved to be higher in athletes compared to physically inactive population (Allen et al., 2011; Kajtna et al., 2004; Król-Zielińska, \& CiekotSołtysiak, 2015). It can be associated with high level of organization, structure of athlete's days, need to have everything under control and great effort to achieve the set goals. The differences were found also between individual and team sports. Individual sport athletes scored higher in Conscientiousness than team sport athletes (Allen et al., 2011; Nia, \& Besharat, 2010). The authors explain this finding with individual tendency to achieve competence and individual motives to achieve performance in individual sport athletes, compared to the team sport athletes who have 
more affiliation and social motives. Individual sport is connected more to self-discipline, responsibility and individual activities. Team sports are based on collective effort (Nia, \& Besharat, 2010). Women scored higher on Conscientiousness than men and athletes competing on higher levels of competition scored also higher on Conscientiousness than low-level athletes (Allen et al., 2011; Tok, 2011). On the other hand, risky sport participants scored lower than other athletes (Tok, 2011). Conscientiousness is a significant predictor of athlete's performance and has significant association with number of played games (Piedmont et al., 1999).

High level of Conscientiousness means high responsibility, organization, order and achievement striving (Costa et al., 1995). It can be assumed, that the extreme high scores can influence athlete's ability to recognize the signs of overload and contribute to ignore the fatigue and some other developing symptoms. It could increase the risk of developing overtraining due to inadequate time for rest and full recovery (MacKinnon, 2000). Due to high level of fatigue, overtraining syndrome influences the ability to plan and follow the scheduled training program. It is related to loss of competitive drive and decrease of motivation to train. If the overload persists for a longer time, athletes start to skip the training sessions (Budgett, 2000; Lavallee et al., 2009; MacKinnon, 2000). Long-term overload could affect the competence, order, self-discipline and achievement striving, that are subscales of dimension of Conscientiousness (Costa et al., 1995).

\section{CONCLUSION}

To conclude it Neuroticism and Conscientiousness were found to be significant predictors of athlete's performance (Piedmont et al., 1999). The differences between athletes and physically inactive population were found for dimension of Neuroticism, Extraversion and Conscientiousness (Allen et al., 2011; Kajtna et al., 2004; Król-Zielińska, \& Ciekot-Sołtysiak, 2015). Also differences between individual and team sports were found in all five dimensions of personality (Allen et al., 2011; Nia, \& Besharat, 2010). Some differences occur also in female and male athletes and in athletes competing on national and international level of competition compared to those competing on regional level of competition (Allen et al., 2011; Tok, 2011). Due to symptoms of overtraining syndrome and areas, that can be affected by it, it is possible to assume certain changes in personality traits, caused by long-term overload of the athletes. Extremely high levels of Neuroticism and Conscientiousness could be considered as possible risk factors for development of overtraining syndrome. Examining the relationship between the personality traits and overtraining syndrome could be an important step towards improving the prevention of development of overtraining syndrome or identification of the symptoms in their early stages. Seeing some extremely high scores in selected personality traits can contribute to expect higher risk of development of overtraining syndrome and knowing how long-term overload could influence the personality traits is seen as an important part of the subsequent treatment. We see the greatest benefit in deepen theoretical knowledge about the overtraining syndrome and possible application of this knowledge in practice, for example creation of a short handbook for coaches of young elite athletes and for their parents, that would include some basic information about possible connection between personality traits and overtraining syndrome. Also differences between individual and team sports should be discussed with coaches and parents of young elite athletes. In the future research the relationship between personality traits and overtraining syndrome should be examined. 


\section{References}

Allen, M. S., Greenlees, I., \& Jones, M. (2011). An investigation of the five-factor model of personality and coping behaviour in sport. Journal of sports sciences, 29(8), 841-850.

Allen, M. S., \& Laborde, S. (2014). The role of personality in sport and physical activity. Current Directions in Psychological Science, 23(6), 460-465.

Blahutková, M., \& Pacholík, V. (2004). Psychologie sportu. Kapitoly ze sportu. Brno: Masarykova univerzita, 67-110.

Budgett, R. (2000). Overtraining and chronic fatigue: The unexplained underperformance syndrome (UPS). International SportMed Journal, 1(3), 1-9.

Costa, P.T., McCrae, R.R. (1985): The NEO Personality Inventory. Manual Form s and Form R. Odessa, Psychological Assessment Resources.

Costa, P. T., \& McCrae, R. R. (1992). Normal personality assessment in clinical practice: The NEO Personality Inventory. Psychological assessment, 4(1), 5.

Costa Jr, P. T., \& McCrae, R. R. (1995). Domains and facets: Hierarchical personality assessment using the Revised NEO Personality Inventory. Journal of personality assessment, 64(1), 21-50.

Costa Jr, P. T., McCrae, R. R., \& Kay, G. G. (1995). Persons, places, and personality: Career assessment using the Revised NEO Personality Inventory. Journal of Career Assessment, 3(2), 123-139.

Costa, S., Oliva, P., \& Cuzzocrea, F. (2014). Motivational aspects and personality correlates of physical exercise behavior. Facta Universitatis, Series: Physical Education and Sport, 83-93.

Egloff, B., \& Gruhn, A. J. (1996). Personality and endurance sports. Personality and Individual Differences, 21(2), 223-229.

Faigenbaum, A. D. (2009). Overtraining in young athletes: How much is too much?. ACSM's Health \& Fitness Journal, 13(4), 8-13.

Faude, O., Kellmann, M., Ammann, T., Schnittker, R., \& Meyer, T. (2011). Seasonal changes in stress indicators in high level football. International journal of sports medicine, 32(4), 259

Hanton, S., Fletcher, D., \& Coughlan, G. (2005). Stress in elite sport performers: A comparative study of competitive and organizational stressors. Journal of sports sciences, 23(10), 1129-1141.

Harwood, C., \& Knight, C. (2009). Stress in youth sport: A developmental investigation of tennis parents. Psychology of sport and exercise, 10(4), 447-456.

Hollander, D., Meyers, M. C., \& LeUnes, A. (1995). Psychological factors associated with overtraining: Implications for youth sport coaches. Journal of Sport Behavior, 18(1), 3.

Ingledew, D. K., Markland, D., \& Sheppard, K. E. (2004). Personality and self-determination of exercise behaviour. Personality and individual differences, 36(8), 1921-1932.

Jones, M. (2003). Controlling emotions in sport. The Sport Psychologist, 17.

Kajtna, T., Tušak, M., Barić, R., \& Burnik, S. (2004). Personality in high-risk sports athletes. Kineziologija, 36(1), 24-34.

Król-Zielińska, M., \& Ciekot-Sołtysiak, M. (2015). The personality of highly trained athletes in view of the big five model. Antropomotoryka. Journal of Kinesiology and Exercise Sciences. 72 (25), 29-34.

Kučera, M., Kolář, P., \& Dylevský, I. (2011). Dítě, sport a zdraví. Galén.

Lavallee, D., Sagar, S. S., \& Spray, C. M. (2009). Coping with the effects of fear of failure in young elite athletes.

Lehnert, M., Novosad, J., \& Neuls, F. (2001). Základy sportovního tréninku I. Olomouc: Hanex

MacKinnon, L. T. (2000). Overtraining effects on immunity and performance in athletes. Immunology and cell biology, 78(5), 502-509.

Matos, N. F., Winsley, R. J., \& Williams, C. A. (2011). Prevalence of nonfunctional overreaching/overtraining in young English athletes. Med Sci Sports Exerc, 43(7), 1287-94.

McCarthy, P. J., Jones, M. V., \& Clark-Carter, D. (2008). Understanding enjoyment in youth sport: A developmental perspective. Psychology of Sport and Exercise, 9(2), 142-156.

McCrae, R. R., \& Costa, P. T. (1996). Toward a New Generation of Personality Theories: Theoretical Contexts for the FiveFactor Model. [In] Wiggins JS (Ed.): The Five-Factor Model of Personality: Theoretical Perspectives. Guilford, New York.

McCrae, R. R., \& Costa Jr, P. T. (1999). A five-factor theory of personality. Handbook of personality: Theory and research, 2, 139-153.

Meeusen, R., Duclos, M., Foster, C., Fry, A., Gleeson, M., Nieman, D., ... Urhausen, A. (2013). Prevention, diagnosis and treatment of the overtraining syndrome: Joint consensus statement of the European College of Sport Science (ECSS) and the American College of Sports Medicine (ACSM). European Journal of Sport Science, 13(1), 1-24.

Nederhof, E., Lemmink, K. A., Visscher, C., Meeusen, R., \& Mulder, T. (2006). Psychomotor speed: possibly a new marker for overtraining syndrome. Sports medicine, 36(10), 817-828.

Nederhof, E., Lemmink, K. A. P. M., Zwerver, J., \& Mulder, T. (2007). The effect of high load training on psychomotor speed. International journal of sports medicine, 28(07), 595-601.

Nia, M. E., \& Besharat, M. A. (2010). Comparison of athletes' personality characteristics in individual and team sports. Procedia-Social and Behavioral Sciences, 5, 808-812.

O'Rourke, D. J., Smith, R. E., Smoll, F. L., \& Cumming, S. P. (2011). Trait anxiety in young athletes as a function of parental pressure and motivational climate: is parental pressure always harmful?. Journal of Applied Sport Psychology, 23(4), 398-412.

O'Sullivan, D. M., Zuckerman, M., \& Kraft, M. (1998). Personality characteristics of male and female participants in team sports. Personality and Individual Differences, 25(1), 119-128.

Paulík, K. (2006). Psychologie sportu. Ostrava: Ostravská univerzita v Ostravě. 
Piedmont, R. L., Hill, D. C., \& Blanco, S. (1999). Predicting athletic performance using the five-factormodel of personality. Personality and Individual Differences, 27(4), 769-777.

Schwebel, F. J. (2015). Comparing the Relative Impact of Parent-and Coach-Initiated Motivational Climates on Young Athletes' Self-Esteem, Performance Anxiety, and Achievement Goal Orientation (Doctoral dissertation, University of Washington).

Sindik, J. (2010). Relationship between big five personality markers with situation-related performance at top Croatian basketball players. Sport Science, 3(2), 34-38.

Slepička, P., Hošek, V., \& Hátlová, B. (2009). Psychologie sportu. Karolinum.

Smith, A. L. (2003). Peer relationships in physical activity contexts: A road less traveled in youth sport and exercise psychology research. Psychology of sport and Exercise, 4(1), 25-39.

Stroebel, L. C. E. (2006). Parental involvement in sport: Perceptions of competitive adolescent swimmers (Doctoral dissertation, University of the Free State).

Tok, S. (2011). The big five personality traits and risky sport participation. Social Behavior and Personality: an international journal, 39(8), 1105-1111.

Woodman, T., \& Hardy, L. (2003). The relative impact of cognitive anxiety and self-confidence upon sport performance: A meta-analysis. Journal of sports sciences, 21(6), 443-457.

\section{Corresponding author:}

sara.huteckova@volny.cz 